\title{
Phytochemicals and biological studies of plants in genus Hedysarum
}

\author{
Yinmao Dong ${ }^{1,3}$, Dongyan Tang ${ }^{1}$, Na Zhang ${ }^{2}$, Yue Li ${ }^{2}$, Chunhong Zhang ${ }^{2}$, Li Li ${ }^{3}$ and Minhui Li ${ }^{2 *}$
}

\begin{abstract}
In China, several species (Hedysarum polybotrys Hand.-Mazz., Hedysarum limprichtii Hlbr., Hedysarum vicioider Turcz. var. Taipeicum Hand.-Mazz. Liu, Hedysarum smithianum, et al.) of genus Hedysarum have a long history of use in traditional Chinese medicine (TCM). In TCM, these plants are used to increase the energy of the body. To date, 155 compounds, including flavonoids, triterpenes, coumarins, lignanoids, nitrogen compounds, sterols, carbohydrates, fatty compounds, and benzofuran, have been isolated from plants of the genus Hedysarum. Various chemical constituents contribute to the antioxidant, anti-tumor, anti-aging, anti-diabetic, and anti-hypertensive properties of these plants. Hedysarum species are used to treat infestation with gastrointestinal nematodes and may support the immune system and peripheral nervous system. In the present review, we summarize the research on the phytochemistry and pharmacology of Hedysarum species, which will be useful for better utilization of these important species in TCM.
\end{abstract}

Keywords: Hedysarum, Chemical constituents, Pharmacology, Utilization, TCM

\section{Review}

\section{Introduction}

Hedysarum is a genus of the family Fabaceae that consists of about 300 species of annual and perennial herbs. Hedysarum species are widely distributed in the temperate northern hemisphere, including Asia, Europe, North Africa, and North America. In China, 42 Hedysarum species are native and their center of distribution is in northwestern and southwestern China, most notably the Hengduan Mountain region [1]. Traditional Chinese medicine (TCM) has been used in China for hundreds of years and continues to play an important role in clinical application. Many species of genus Hedysarum, such as Hedysarum polybotrys Hand.-Mazz., Hedysarum limprichtii Hlbr., Hedysarum vicioider Turcz. var. Taipeicum Hand.-Mazz. Liu, and Hedysarum smithianum have been employed in TCM to strengthen the immune system and improve the energy of the body. The root of $H$. polybotrys, which is commonly known as "Hongqi" or "Radix Hedysari" is an important component of various TCM formulas. $H$. polybotrys was

\footnotetext{
* Correspondence: li_minhui@yahoo.cn

Baotou Medical College, No. 31 Construction Road, Baotou, Inner Mongolia 014060, P. R. China

Full list of author information is available at the end of the article
}

recorded in Chinese Pharmacopoeia 2010 [2]. The traditional curative functions of Hongqi are to invigorate "Qi", increase urination, and promote tissue regeneration [2]. Biological studies have shown that Hongqi, which contains a large quantity of polysaccharides, has antiaging, antioxidant, anti-tumor, and anti-diabetic activity. Hongqi is reported to have great potential for use in modern health food and plant cosmetics [1-5]. The phytochemistry and pharmacology of Hedysarum species have attracted increasing worldwide attention among those involved in the research and development of new drugs. In the present review, we summarize and list all of the secondary metabolites that have been identified in plants of genus Hedysarum over the past few decades. We also consider the pharmacological activity of Hedysarum species, which will be useful for better utilization of the important Hedysarum species in TCM formulas.

\section{Chemical constituents}

Over the past few decades, 155 chemical constituents have been isolated from plants of genus Hedysarum through different chromatography methods and were identified by the spectrum of ${ }^{1} \mathrm{H}-\mathrm{NMR},{ }^{13} \mathrm{C}-\mathrm{NMR}, 2 \mathrm{D}$ NMR, HR/MS, et al. [3-5]. The chemical structures of
(C) Chemistry Central

(c) 2013 Dong et al.; licensee Chemistry Central Ltd. This is an Open Access article distributed under the terms of the Creative Commons Attribution License (http://creativecommons.org/licenses/by/2.0), which permits unrestricted use, distribution, and reproduction in any medium, provided the original work is properly cited. 
these constituents include flavonoids (1-79), triterpenes and triterpenoid saponins (80-91), coumarins (92-103), lignanoids (104-105), nitrogen compounds (106-112), sterols (113-117), carbohydrates (118-123), fatty compounds (124-135), benzofuran (136-145), and others (147-155). The names and corresponding plant resources are compiled in Table 1 and the chemical structures are described in Additional file 1. In recent years, some polysaccharides were isolated from the species of genus Hedysarum by aqueous extract followed by precipitation with ethanol. The homogeneous polysaccharide was obtained after treated with Savage method and $\mathrm{H}_{2} \mathrm{O}_{2}$, and purified with and Sephadex G-200 gel filtration chromatography. Then GC, HPGC, GPC-MALLS, elemental analyzer, phenol sulfuric acid method and Bradford method were used to study the physicochemical property of the polysaccharides [6].

Among the important chemical constituents, flavonoids are usually regarded as the main groups of metabolites and quality control markers in genus Hedysarum. Polysaccharides with perfect pharmacological activities are important research direction in future.

\section{Flavonoids}

Flavonoids are a large group of polyphenolic compounds found in genus Hedysarum. So far, 79 flavonoids (flavones, flavonones, isoflavones, chalcones, flavanols, xanthones, and pterocarpans) have been identified and categorized based on chemical structure. Flavones are the most common and predominant flavonoids in genus Hedysarum. To date, 21 flavones (1-21) and three flavonones (22-24) have been isolated from plants of genus Hedysarum $[7,8,10-12,14,16,18,20]$. The flavonones are naringin and naringin-type's derivatives and are mainly distributed in $H$. multijugum and $H$. polybotrys. Isoflavones are ubiquitous secondary metabolites in genus Hedysarum. So far, 31 isoflavones (25-55) have been isolated from plants in this genus. $H$. polybotrys, $H$. multijugum, and $H$. scorparium have particularly high concentrations of isoflavones [19-21,24,28-30,32-35]. Four chalcones (56-59) have been isolated from Hedysarum species. Isoliquiritigenin (56) was isolated from $H$. polybotrys, while compounds (57-59) were obtained from H. gmelinii [21,36]. Five flavanols (60-64) have been identified in genus Hedysarum species. All these compounds were found in $H$. theinum and $H$. kirghisorum [22,23]. Four xanthones (65-68) have been identified plants of genus Hedysarum. Mangiferin (65) was found in $H$. aericeum, $H$. havescen, $H$. denticulatum, $H$. komarovii, $H$. sachalinense, $H$. neglectum, H. connatum, and $H$. alpinum. Isomangiferin (66) was obtained from $H$. havescen, $H$. denticulatum, $H$. connatum, and $H$. alpinum. Glucomangiferin (67) and glucoisomangiferin (68) were isolated from $H$. flavescents [15,37-39]. Eleven pterocarpans (69-79) have been isolated and identified from genus
Hedysarum [41,42]. These structures can be classified as isoflavones.

Although most species of genus Hedysarum contained different kinds of flavonoids, but the types and contents of flavonoids showed differences among species. For example, content of mangiferin and sum of xanthones in the leaves of 7 species ( $H$. alpinum, $H$. flavescens, $H$. austrosibiricum, $H$. neglectum, $H$. theinum, $H$. gmelinii and $H$. tschuense), growing on the forest-steppe zone of Western Siberia (Novosibirsk) and in natural populations Republic Altai and Northern Kazakhstan was studied. The greatest amount of mangiferin and the sum of xanthones was revealed in leaves of $H$. alpinum and $H$. flavescens (to 4.3 and 6.0\%). H. austrosibiricum, $H$. neglectum and $H$. theinum contained almost twice less than them. H. gmelinii contained about $1.0 \%$. Xanthones were absent in leaves of $H$. tschuense. Cultivated plants synthesize more xanthones, than wild-growing [55]. Five major flavonoids in 48 batches of Radix Hedysari from different origins were simultaneously evaluated by HPLC. Among the 5 major flavonoids, ononin, formononetin-7-O$\beta$-D- glucopyranoside-6"-O-malonate, formononetin and medicarpin, were detected in almost all the samples and thus can be used as marker compounds to evaluate the quality of Radix Hedysari, while naringin was not detected in most samples. Further analysis of the contents of the 4 flavonoids in different samples showed that processing procedure, harvesting time and habitats were important factors affecting the flavonoid contents of Radix Hedysari [19].

\section{Triterpenoids}

Twelve triterpenoids (80-91) were isolated from plants of genus Hedysarum, most of which were distributed in H. polybotrys $[9,17,44,45,47,48]$.

\section{Coumarins}

Twelve coumarins have so far been isolated from this genus. Compounds 92-102 were obtained from $H$. multijugum, while 3,9-dihydroxy coumestan (103) was isolated from H. gmelinii $[9,30,49]$.

\section{Lignanoids}

Only 2 lignanoids have been identified from Hedysarum species: syringaresinol (104) from $H$. polybotrys and isolariciresinyl-9' -O- $\beta$-D-glucopyranoside (105) from $H$. setigerum $[27,50]$.

\section{Nitrogen compounds}

Five alkaloids (106-110) and 2 amino acids (111-112) have been isolated from the genus $[25,40,50]$. 
Table 1155 compounds of the genus Hedysarum

No. Compound class and name

Flavones

1 4'-methoxy-7-hydroxyflavone

2 Narcissin

3 Apigenin

4 5,7-dihydroxy-4'-methoxyflavone

5 Isorhamnetin

6 3-O-Methylkaempferol

7 Quercetin 3-a-L-rhamnofuranoside

8 Quercetin 3- $a$-L-arabinofuranoside

9 Polystachoside (quercetin3- $\beta$ - $L$-arabinofuranoside)
Source ref.

H. polybotrys

[4]

H. multijugum [7]

H. multijugum [7]

H. scoparium [8]

H. setigerum [9]

H. setigerum [10]

H. gmelinii [11]

H. neglectum [12]

H. gmelinii [11]

H. connatum [13]

H. alpinum [13]

H. komarovii [14]

H. sachalinense [15]

H. neglectum [12]

H. connatum [13]

H. alpinum [13]

H. setigerum [9]

H. setigerum [9]

H. setigerum [9]

H. setigerum [10]

H. setigerum [10]

H. setigerum [10]

H. aericeum [16]

H. caucasium

H. austrosibiricum [17]

H. aericeum [16]

H. caucasium [16]

H. setigerum [10]

H. connatum [13]

H. alpinum [13]

H. aericeum [16]

H. caucasium [16]

H. aericeum [16]

H. caucasium [16]

H. aericeum [16]

H. caucasium [16]

H. komarovii [14]

H. sachalinense [15]

H. neglectum [12]

H. connatum [13]

H. alpinum [13] 
Table 1155 compounds of the genus Hedysarum (Continued)

21 Quercitrin

$\begin{array}{ll}\text { H. setigerum } & {[10]} \\ \text { H. connatum } & {[13]} \\ \text { H. alpinum } & \text { [13] }\end{array}$

Flavonones

22 Naringenin-5,7-di-O- $\beta$-D-glucopyranoside

H. multijugum

H. polybotrys

[7]

23 Naringin

H. polybotrys

$[18,19]$

24 Naringenin

.

Isoflavones
25 6"-O-acetylononin
26 Ononin-6"-O-malonate
27 Ononin

28 Formononetin

29 Calycosin

30 5,7-dihydroxy-6-C-prenyl-4'-methoxy -isoflavone (Gancaonin A)

31 5,7-dihydroxy-6,8-di-C-prenyl-4'- methoxy-isoflavone

32 5,7-dihydroxy-4'-methoxy-isoflavone

33 5,7-dihydroxy-8-C-prenyl-4'-methoxy isoflavone (gancaonin M)

34 Osajin 4'-methyl ether

35 Sissotrin

36 Afromosin-7-O- $\beta$-D-glucopyranoside

37 Calycosin-7-O- $\beta$-D-glucopyranoside

38 Warangalone 4'-methyl ether

39 Afrormosin

40 5-hydroxy-4'-methoxy-6-prenyl-2'"- hydroxyisopropylfurano [4,5:8,7]-isoflavone

41 5-hydroxy-4'-methoxy-6-prenylfurano [4,5:6,7]-isoflavone

42 5-hydroxy-4'-methoxy-8-prenylfurano [4,5:6,7]-isoflavone

43 5-hydroxy-4'-methoxy-8-prenyl-2" - hydroxyisopropyldihydrofurano $[4,5: 6,7]-i s o f l a v o n e$

\begin{tabular}{|c|c|}
\hline H. theinum & [3] \\
\hline H. polybotrys & {$[19,20]$} \\
\hline H. polybotrys & {$[18,19]$} \\
\hline H. polybctrys & {$[20,21]$} \\
\hline H. multijugum & [7] \\
\hline H. kirghisorum & {$[22,23]$} \\
\hline H. semenovii & [24] \\
\hline H. austrosibiricum & {$[25]$} \\
\hline H. theinum & {$[3,26]$} \\
\hline $\begin{array}{l}\text { H. polybotrys } \\
\text { H. polybotrys }\end{array}$ & $\begin{array}{l}{[19,20]} \\
{[21,27]}\end{array}$ \\
\hline H. multijugum & [28] \\
\hline H. semenovii & [24] \\
\hline H. austrosibiricum & {$[25]$} \\
\hline H. kirghisorum & {$[22,23]$} \\
\hline H. polybctrys & [21] \\
\hline H. semenovii & [24] \\
\hline H. multijugum & {$[29,30]$} \\
\hline H. multijugum & {$[29,30]$} \\
\hline H. scoparium & {$[8]$} \\
\hline H. multijugum & [28] \\
\hline H. kirghisorum & [23] \\
\hline H. multijugum & {$[28,30]$} \\
\hline H. scoparium & {$[8]$} \\
\hline H. multijugum & {$[7,30]$} \\
\hline H. kirghisorum & {$[22,23]$} \\
\hline H. semenovii & [24] \\
\hline H. semenovii & [24] \\
\hline H. multijugum & [7] \\
\hline H. scoparium & {$[8]$} \\
\hline H. multijugum & [7] \\
\hline H. kirghisorum & {$[22,23]$} \\
\hline H. semenovii & {$[24]$} \\
\hline H. scoparium & [8] \\
\hline H. scoparium & {$[8]$} \\
\hline H. scoparium & {$[8]$} \\
\hline H. scoparium & {$[8,31]$} \\
\hline
\end{tabular}

H. theinum 


\section{Table 1155 compounds of the genus Hedysarum (Continued)}

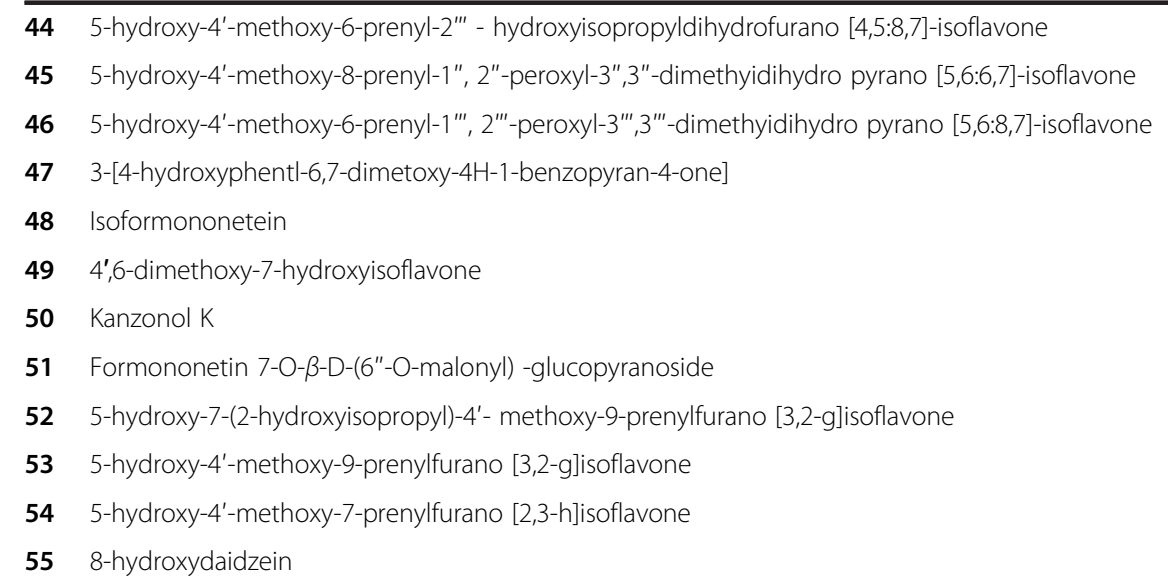

Chalcones
56 Isoliquiritigenin
57 Hedysarumine A
58 Hedysarumine $B$
59 Paratocarpin $\mathrm{E}$
Flavanols
60 (-)-catechin
61 (-)-epicatechin
62 (-)-epigallocatechin
63 (-)-vestitol
64 Plumbocatechin

$\begin{array}{ll}\text { H. scoparium } & {[8,31]} \\ \text { H. scoparium } & {[8,31]} \\ \text { H. scoparium } & {[8,31]} \\ \text { H. sikkimense } & {[32]} \\ \text { H. sikkimense } & {[32]} \\ \text { H. theinum } & {[33]} \\ \text { H. multijugum } & {[30]} \\ \text { H. polybotrys } & {[34]} \\ \text { H. scoparium } & {[35]} \\ \text { H. scoparium } & {[35]} \\ \text { H. scoparium } & {[35]} \\ \text { H. theinum } & {[3]}\end{array}$

$\begin{array}{ll}\text { H. polybctrys } & {[21,27]} \\ \text { H. gmelinii } & {[36]} \\ \text { H. gmelinii } & {[36]} \\ \text { H. gmelinii } & {[36]}\end{array}$

Xanthones

65 Mangiferin

$\begin{array}{ll}\text { H. theinum } & {[3]} \\ \text { H. theinum } & {[3]} \\ \text { H. kirghisorum } & {[22,23]} \\ \text { H. kirghisorum } & {[22,23]} \\ \text { H. theinum } & {[3,26]} \\ \text { H. kirghisorum } & {[22,23]}\end{array}$

$\begin{array}{ll}\text { H. aericeum } & {[16]} \\ \text { H. caucasium } & {[16]} \\ \text { H. flavescens } & {[37]} \\ \text { H. alpinum } & {[37]} \\ \text { H. denticulatum } & {[38]} \\ \text { H. komarovii } & {[14]} \\ \text { H. sachalinense } & {[15]} \\ \text { H. neglectum } & {[12]} \\ \text { H. connatum } & {[13]} \\ \text { H. alpinum } & {[13]} \\ \text { H. flavescens } & {[37]} \\ \text { H. alpinum } & {[37]} \\ \text { H. denticulatum } & {[38]} \\ \text { H. connatum } & {[13]} \\ \text { H. alpinum } & {[13]} \\ \text { H. flavescens } & {[39]} \\ \text { H. flavescens } & {[39]}\end{array}$

67 Glucomangiferin

H. flavescens 
Table 1155 compounds of the genus Hedysarum (Continued)

Pterocarpans

69 (-)-medicarpin

$\begin{array}{ll}\text { H. theinum } & {[3,26]} \\ \text { H. polybotrys } & {[6,20]} \\ \text { H. Semenovii } & {[40]} \\ \text { H. multijugum } & {[28]} \\ \text { H. multijugum } & {[30]} \\ \text { H. multijugum } & {[30]} \\ \text { H. multijugum } & {[30]} \\ \text { H. multijugum } & {[30]} \\ \text { H. multijugum } & {[30]} \\ \text { H. multijugum } & {[30]} \\ \text { H. multijugum } & {[30,41]} \\ \text { H. polybotrys } & {[42]} \\ \text { H. polybotrys } & {[4,27]} \\ \text { H. taipeicum } & {[43]} \\ \text { H. semenovii } & {[40]} \\ \text { H. gmelinii } & {[44]} \\ \text { H. multijugum } & {[41]} \\ \text { H. polybotrys } & {[42]}\end{array}$

Triterpennoids

80 Lupeol

$\begin{array}{ll}\text { H. polybotrys } & {[4]} \\ \text { H. scoparium } & {[8]} \\ \text { H. sikkimense } & {[32]} \\ \text { H. gmelinii } & {[44]} \\ \text { H. scoparium } & {[8]} \\ \text { H. polybctrys } & {[45]} \\ \text { H. multijugum } & {[28]} \\ \text { H. semenovii } & {[40]} \\ \text { H. sikkimense } & {[32]} \\ \text { H. gmelinii } & {[44]} \\ \text { H. polybotrys } & {[5,46]} \\ \text { H. polybotrys } & {[18]} \\ \text { H. multijugum } & {[47]} \\ \text { H. polybotrys } & {[5,46]} \\ \text { H. polybotrys } & {[18]} \\ \text { H. multijugum } & {[47]} \\ \text { H. polybotrys } & {[5,46]} \\ \text { H. polybctrys } & {[18]} \\ \text { H. multijugum } & {[47]} \\ \text { H. multijugum } & {[47]} \\ \text { H. gmelinii } & {[44]} \\ \text { H. polybotrys } & {[5,46]} \\ \text { H. polybctrys } & {[48]} \\ \text { H. polybctrys } & {[48]}\end{array}$

91 Polybosaponin A

$\begin{array}{ll}\mathbf{8 1} & \text { 12-hydroxylupeol } \\ \mathbf{8 2} & \text { Betulinic acid }\end{array}$

83 Ursolic acid

84 Soyasapogenol

85 Soyasaponinllmethyl ester

86 Soyasaponinl

87 Soyasaponinll

88 Soyasaponin $\mathrm{Bg}$

89 Squasapogenol

90 Dehydrosoyasaponin 1
[4] 
Table 1155 compounds of the genus Hedysarum (Continued)

Coumarins
92 Aureol
93 Hedysarimcoumestan E
94 Hedysarimcoumestan B
95 Hedysarimcoumestan A
96 Hedysarimcoumestan F
97 Hedysarimcoumestan D
98 Hedysarimcoumestan $G$
99 Hedysarimcoumestan $\mathrm{H}$
100 Hedysarimcoumestan C
101 Methylhedysarimcoumestan $\mathrm{H}$
102 1,3,9-trimethoxycoumestan
103 3,9-dihydroxy coumestan
Lignanoids

$104(+)$ syringaresinol

105 (+)-isolariciresinyl-9'-O- $\beta$-D-glucopyranoside

Alkaloids

106 Guanosine
107 Docosanooic acid-2,3-dihydroxyproyl ester
108 Protocatechoic acid
109 Tryptophane
110 Sparaginic acid
111 Hypaphorine
112 Berberine

Sterols

113 Stigmasterol

114 Daucosterol

$115 \beta$-sitosterol

$$
\begin{array}{ll}
\text { H. multijugum } & {[30,49]} \\
\text { H. multijugum } & {[30,49]} \\
\text { H. multijugum } & {[30,49]} \\
\text { H. multijugum } & {[30,49]} \\
\text { H. multijugum } & {[30,49]} \\
\text { H. multijugum } & {[30,49]} \\
\text { H. multijugum } & {[30,49]} \\
\text { H. multijugum } & {[30,49]} \\
\text { H. multijugum } & {[49]} \\
\text { H. multijugum } & {[30]} \\
\text { H. multijugum } & {[49]} \\
\text { H. gmelinii } & {[44]}
\end{array}
$$

H. polybotrys

[27]

H. setigerum

H. semenovii

H. sikkimense [32]

H. theinum

H. polybctrys

H. austrosibiricum [25]

H. polybctrys [18]

H. setigerum

H. multijugum

H. polybotrys

H. semenovii

H. scoparium

[8]

H. austrosibiricum [17]

H. polybotrys

H. multijugum

H. taipeicum

H. scoparium

[8]

H. austrosibiricum

H. sikkimense

H. gmelinii [44]

$1167 \beta$-hydroxysitosterol

H. scoparium [8]

117 7a-hydroxysitosterol

H. scoparium

[8]

Carbohydrates

118 Rhamnose

H. polybctrys [7,51]

H. polybctrys $\quad[7,51]$

H. polybctrys $\quad[7,51]$

120 Xylose

121 Galactose

H. polybctrys $\quad[7,51]$ 
Table 1155 compounds of the genus Hedysarum (Continued)

\begin{tabular}{|c|c|c|c|}
\hline 122 & Glucose & H. polybctrys & {$[7,51]$} \\
\hline \multirow[t]{4}{*}{123} & Sucrose & H. polybctrys & [45] \\
\hline & & H. taipeicum & [43] \\
\hline & & H. austrosibiricum & [17] \\
\hline & & H. sikkimense & {$[32]$} \\
\hline \multicolumn{4}{|c|}{ Fatty compounds } \\
\hline \multirow[t]{2}{*}{124} & $\eta$-hexacosanoic acid (Cerinic acid) & H. polybctrys & {$[4,27]$} \\
\hline & & H. taipeicum & [43] \\
\hline \multirow[t]{6}{*}{125} & $\eta$-tetracosanoic acid & H. polybctrys & [27] \\
\hline & & H. multijugum & [29] \\
\hline & & H. scoparium & [8] \\
\hline & & H. taipeicum & [43] \\
\hline & & H. sikkimense & [32] \\
\hline & & H. theinum & [26] \\
\hline 126 & Trioleic glyceride & H. polybctrys & [27] \\
\hline 127 & Glycerol monopalmitate & H. polybctrys & [27] \\
\hline 128 & Behenic & H. theinum & [26] \\
\hline \multirow[t]{2}{*}{129} & Palmitic acid & H. theinum & [26] \\
\hline & & H. gmelinii & [44] \\
\hline 130 & Linoleic acid & H. theinum & [26] \\
\hline 131 & Oleic acid & H. theinum & [26] \\
\hline 132 & Hexacosyl acetate & H. taipeicum & [43] \\
\hline 133 & Hexadecanoic acid 2,3-dihydroxypropyl ester & H. gmelinii & [44] \\
\hline 134 & Triacontyl alcohol & H. multijugum & [29] \\
\hline 135 & n-tetracosanol & H. scoparium & [8] \\
\hline \multicolumn{4}{|c|}{ Benzofuran } \\
\hline 136 & Ebenfuranll & H. multijugum & [30] \\
\hline 137 & HedysarimbenzofuranB & H. multijugum & {$[30,52]$} \\
\hline 138 & AndinermalC & H. multijugum & {$[30]$} \\
\hline 139 & 2-(2,4,6-trihydroxypheny)-3-formyl-4- hydroxy-5-methoxy-6 (3-methyl-but-2- enyl) benzofuran & H. multijugum & [30] \\
\hline 140 & $\begin{array}{l}\text { 2-(2,6-dihydroxy-4-methoxypheny)-4- hydroxy-3-(hydroxymethyl)-5/6-metho xy-6/5-(3-methyl-but-2-enyl) } \\
\text { benzofuran }\end{array}$ & H. multijugum & [30] \\
\hline 141 & 2-(2,6-dihydroxy-4-methoxypheny)-3- formyl-4-hydroxy-5/6-methoxy-6/5-(3-methyl-but-2-enyl)benzofuran & H. multijugum & [30] \\
\hline 142 & 2-(2-hydroxy-4,6-dimethoxyphenyl)-3-formyl-4-hydroxy-5/6-methoxy-6/5-(3-methyl-but-2-enyl)benzofuran & H. multijugum & [30] \\
\hline 143 & Hedysarimbenzofuran A & H. multijugum & {$[30,52]$} \\
\hline 144 & 5-hydroxy-2-(2-hydroxy-4-methoxyphenyl)-6-methoxybenzofuran & H. polybotrys & [42] \\
\hline 145 & 6-hydroxy-2-(2-hydroxy-4-methoxyphenyl)-benzofuran & H. polybotrys & [42] \\
\hline \multicolumn{4}{|c|}{ Others } \\
\hline 146 & Raspberry ketone & H. theinum & {$[3,26]$} \\
\hline 147 & Rhododendrol & H. theinum & {$[3,26]$} \\
\hline 148 & Cetyl ferulate & H. polybotrys & {$[4,27]$} \\
\hline 149 & Polybotrin & H. polybotrys & [53] \\
\hline 150 & Hedysalignan A & H. polybctrys & [21] \\
\hline 151 & 4'-hydrox-y-trans-cinnamic acid docosyl ester & H. multijugum & [29] \\
\hline 152 & Caffeic acid tetracosyl ester & H. multijugum & [29] \\
\hline
\end{tabular}


Table 1155 compounds of the genus Hedysarum (Continued)

\begin{tabular}{llll}
\hline 153 & p-hydroxybenzoic acid & H. setigerum & [50] \\
154 & (E)-3-(4-hydroxy-2-methoxyphenyl)-prope noicacid4-hydroxy-3-methoxyphenyl ester & H. polybotrys & [54] \\
155 & Protocatechoic acid & H. setigerum & [50] \\
\hline
\end{tabular}

\section{Sterols}

The sterols found in genus Hedysarum include stigmasterol (113), daucosterol (114), sitosterol (115), and 2 derivations of sitosterol (116 and 117) [28,29].

\section{Carbohydrates}

There are 6 carbohydrates that have been isolated from Hedysarum species. Five of these carbohydrates were isolated from $H$. polybotrys, including rhamnose (118), arabinose (119), xylose (120), galactose (121), and glucose (122). Sucrose (123) was obtained from $H$. polybotrys, $H$. taipeicum, H. austrosibiricum, and H. sikkimense [56,57].

\section{Fatty compounds}

Twelve fatty compounds, including seven fatty acids (124, $125,128-131,134), 3$ fatty alcohols $(127,132,135)$, and 2 others $(126,133)$ have been identified in plants of genus Hedysarum $[26,43]$.

\section{Benzofurans and benzene derivatizations}

Ten benzofurans have been found in genus Hedysarum. Compounds 136-143 were isolated from $H$. multijugum. Compounds 144 and 145 were obtained from $H$. polybotrys. About 10 (146-155) have been obtained from Hedysarum species [52-54].

\section{Polysaccharides and condensed tannins}

HPS4-1A is a new neutral heteropolysaccharide from $H$. polybotrys. The absolute and relative molecular weight of HPS4-1A was $7.386 \times 10^{4}$ and above $6.68 \times 10^{5}$, respectively. It was consisted of L-rhamnose, L-arabinose, D-glucose and D-galactose (1:2:1:2). HPS4-1A was proved to be a neutral sugar, with 1,6- and 1,2,6- $\alpha$-D-galactopyranosyl and 1,5 - and 1,3,5- $\alpha$-L-arabinofuranosyl residues in backbone, and 1,4- and 1,4,6- $\alpha$-D-glucopyranosyl and 1,2- and 1,2,4$\alpha$-L- rhamnofuranosyl residues in branches. Arabinose mainly connected the end of backbone, and glucose and a small quantity of arabinose mainly connected the end of branches. HPS4-1A has a random coil state conformation with monodisperse mass distribution [6].

Water soluble sulfated glucan (SHG) was isolated from $H$. polybotrys using anion-exchange and gel-permeation chromatogram. Elemental analysis indicated that SHG was a sulfated polysaccharide with small amount of sulfate groups (1.47\%). The molecular weight was $1.72 \times 10^{5} \mathrm{Da}$. Compositional analysis revealed that SHG was composed of glucose only. SHG was composed of $\alpha$-D- $(1 \rightarrow 4)$-linked glucopyranosyl residues, with branches at C-6 consisting of non-reducing terminal approximately every eight residues. Sulfate groups may attach to the backbone at O-6, occasionally occurring per thirty-eight anhydrous glucose units [58].

The chemical characteristics of the purified condensed tannin fractions were studied by acid-catalyzed degradation with benzyl mercaptan and electrospray ionization mass spectrometry (ESI-MS). Thiolysis revealed that epigallocatechin was the major extender unit $(15-75 \%)$ while gallocatechin was the major terminal unit (50-66\%), thus indicating the extractable sulla condensed tannin fraction as the prodelphinidin type [59].

\section{Pharmacological activities}

The species of genus Hedysarum, such as Hongqi (Hedysarum polybotrys Hand.-Mazz.), showed pharmacological activity in modern experiments and are potential antioxidant, anti-aging, anti-tumor, immune system regulatory, and anti-diabetic agents.

\section{Antioxidant activity}

Free radicals are formed by various environmental chemicals and the endogenous metabolism of plants. With the development of biomedical science, the involvement of free radicals in many diseases, such as brain dysfunction, cancer, and heart disease, has become well known. Antioxidant substances that fight free radicals have a crucial role in human health. Some of the chemicals extracted from plants of genus Hedysarum are reported to possess strong antioxidant properties. For example, polysaccharide HPS-3 from the radix of $H$. polybotrys (Hedysari, Hongqi) showed antioxidant activity in superoxide anion $\left(\mathrm{O}^{2-}\right)$, hydroxyl radical $(\cdot \mathrm{OH}), 2$,2-diphenyl-1-picrylhydrazyl (DPPH) free radical-scavenging, and $\mathrm{H}_{2} \mathrm{O}_{2}$ assays. At concentrations of 0.05 to $5.00 \mathrm{mg} / \mathrm{mL}$, the maximum removal efficiency for $\mathrm{O}^{2-}, \mathrm{H}_{2} \mathrm{O}_{2}, \cdot \mathrm{OH}$, and $\mathrm{DPPH}$ were $55.92 \%, 59.32 \%, 53.69 \%$, and $87.66 \%$, respectively. The effects were concentration dependent [60].

Compound 27, isolated from $H$. polybotrys, can improve the survival rate of SH-SY5Y cells and $\mathrm{H}_{2} \mathrm{O}_{2}$-injured DJ-1 gene-transfected SH-SY5Y cells, as indicated by the 3-(4,5dimethylthiazol-2-yl)-2,5-diphenyl tetrazolium bromide (MTT) method. The addition of compound $27(20 \mathrm{mg} / \mathrm{L})$ more obviously improved the cell viability for DJ-1 gene transfected SH-SY5Y cells (cell viability of 91\%) than the 
normal SH-SY5Y cells (cell viability of 83\%). This indicates that compound 27 had a protective effect against the oxidative damage induced by hydrogen peroxide [18].

\section{Anti-aging activity}

Aging is a natural process. Anti-aging compounds can suppress and retard the aging process of the body. A polysaccharide found in $H$. polybotrys (HPS) can prompt protein synthesis by affecting cellular RNA content, thereby repairing cell dysfunction caused by aging and other reasons [61]. HPS directly clears lipid peroxides (LPO) and significantly improve the superoxide dismutase (SOD) activity of rabbit aorta smooth muscle cells (SMC), to a greater degree than a positive control, VE. Moreover, there is a significant improvement of SOD content in the erythrocytes of aged rats, which indicates that the antiaging activity of HPS in aged rats is due to activation of antioxidases [62]. Aqueous extracts of $H$. austrosibiricum from Xinjiang province significantly decreased the malondialdehyde (MDA) content of liver and brain tissues of aging mice after induction by $\mathrm{D}$-galactose. These extracts also markedly increased the activities of SOD and glutathion peroxidase (GSH-Px). In addition, monoamine oxidase (MAO) activity in the brain tissue decreased and the spleen and thymus indexes were elevated after treatment with the aqueous extract. $H$. austrosibiricum showed anti-aging activity by eliminating free radicals and activating antioxidases [63].

\section{Immune system regulation activity}

The immune system finds and removes foreign pathogenic microorganisms that cause fluctuations in the internal environment of the body. A polysaccharide from $H$. polybotrys (HPS) has obvious protective effects on the immune system that are similar to Astragalus membranaceus polysaccharide (APS). Both HPS and APS can increase the celiac macrophage phagocytic function of mice and correct inhibition of cell-mediated immunity caused by cyclophnosphamide (CY) and PDS. HPS and APS also improve lymphocyte transformation in vivo and significantly increase the concentration of phenol acetate esterase-positive (ANAE) lymphocytes in the fluid sampled [64]. HPS enhances humoral and cellular immune function. The lymphocyte proliferation rate in vivo was remarkably increased $(P<0.001)$ and inhibition of $C Y$ was completely corrected $(P<0.001)$ by HPS $(0.5 \mathrm{~g} / \mathrm{kg})[65]$.

RHTS (total saponins extracted from $H$. polybotrys) obviously improved immune function suppressed by $\mathrm{CY}$. The index for the function of the thymus and the spleen were increased. The phagocytic index and phagocytic percentage of intraperitoneal macrophages were significantly increased $(P<0.05)$. CaM levels in cells of thymocytes, erythrocytes, and macrophages showed obvious correlation with immune function, which suggests that the $\mathrm{Ca}^{2+}-\mathrm{CaM}$ signal system plays an important role in the immune cell activation process [66]. Aqueous extracts of $H$. polybotrys and $A$. membranaceus intensify the functions of normal macrophages and those treated with $10 \mathrm{ng} / \mathrm{mL}$ LPS, as indicated by NO released by the cells. The activities of $H$. polybotrys and A. membranaceus ethanol extracts were not better than those of the aqueous extracts [67].

The regulating effects of Hedysari Radix and Astragali Radix alternative classic tonification prescriptions on humoral immunity in immunosuppressed mice were compared. The immunosuppressed mouse model was induced by cyclophosphamide. The mice were administered intragastically with the same dose of Hedysari Radix and Astragali Radix alternative the formula Buzhong Yiqi Yangxue, Yupingfeng oral liquid and Fuqi Zhihan granules for antagonistic experiments in vivo. Spleen index, HC50, $\mathrm{CD} 19^{+}$B lymphocyte subgroup and content of serum IL-4 were detected after treatment. Both groups of Hedyseri Radix and Astragali Radix could antagonize immunosuppressive action caused by cyclophosphamide. They both could significantly raise spleen index, $\mathrm{HC} 50, \mathrm{CD} 19^{+} \mathrm{B}$ lymphocyte subgroup and content of serum IL-4 in different degree. Yupingfeng water extraction of Hedysari Radix substitute Astragali Radix was better than Yupingfeng oral liquid in raising spleen index. There were no significant differences among the rest Hedysari Radix and Astragali Radix alternative groups. Hedysari Radix compatibility with other drugs compared with original prescription has similar role in humoral immunity regulation [68].

\section{Anti-tumor activity}

Malignant tumors (cancer) are among the leading causes of death. The main bioactive chemicals found in plants of genus Hedysarum play an important role in the prevention of several tumor cell types. MTT assays revealed that HPS-1 that was obtained from the roots of $H$. polybotrys significantly inhibited the proliferation of human hepatocellular carcinoma HEP-G2 cells and human gastric cancer MGC-803 cells in vitro. At concentrations from 50 to $400 \mu \mathrm{g} / \mathrm{mL}$, HPS-1 significantly inhibited the proliferation of HEP-G2 cells $(P<0.05)$ in a concentration-dependent manner. At $400 \mu \mathrm{g} / \mathrm{mL}$, HPS-1 had an inhibition ratio of $40.0 \%$. However, although HPS-1 also significantly suppressed MGC-803 cells $(P<0.05)$, there was no clear relationship between the concentration of HPS-1 and its effects. These results indicate that HPS-1 has potential for cancer therapy [69]. In addition, the cytotoxicity of the purified compounds against human cancer cell line HepG2 was evaluated using the MTT method. Compound 78 showed inhibitory activity on $\mathrm{HepG} 2$ with $\mathrm{IC}_{50}$ values of $10.69 \mu \mathrm{mol} / \mathrm{L}$ [27]. 


\section{Anti-diabetic properties}

HPS is the principal active fraction responsible for the anti-diabetic properties of $H$. polybotrys. In ones study of the hypoglycemic activity of HPS, crude HPS was isolated, purified, and divided into 4 fractions of different molecular weight ranges. ALX treatment of mice produced a significant increase in fasting hyperglycemia, which was counteracted by treatment with HPS1, HPS3, and HPS4. A dose of $200 \mathrm{mg} / \mathrm{kg}$ HPS3 caused the maximum reduction in blood glucose level (56\% at 12 days of HPS3 administration) and this effect was greater than that of the oral hypoglycemic agent metformin. Plasma insulin concentration and ISI were significantly higher in the HPS3treated mice than in mice of the diabetes mellitus (DM) model control group. Moreover, HPS3 inhibited the secretion of tumor necrosis factor- $\alpha$ (TNF- $\alpha$ ), leptin, and free fatty acid (FFA) levels by improving insulin secretion, promoting glucose uptake, suppressing gluconeogenic precursors, and decreasing glucose oxidation and output. Thus, HPS3 improved insulin resistance in diabetic mice. The beneficial effects of HPS3 also included the reduction of lipid peroxidation (increased NOS and SOD activity, increased T-AOC and NO, as well as decreased MDA) in STZ-induced diabetic rats [70].

\section{Effects on the peripheral nervous system}

The effects of HPS on sciatic nerve regeneration in rats for 6 weeks following clamping of the nerve (HPS was administrated orally as $2 \mathrm{~mL}$ liquid daily, $0.25 \mathrm{~g} \mathrm{HPS} / \mathrm{mL}$ ) were examined. HPS improved sciatic function index (SFI) values, tibial function index (TFI) values, peroneal nerve function index (PFI) values, conduction velocity, and the number of regenerated myelinated nerve fibers, suggesting the potential clinical application of HPS for the treatment of peripheral nerve injury in humans [71].

\section{Others}

H. polybotrys has significant protective effect against heart and brain hypoxia. In study of Yasuda-chiari cerebral ischemia anoxia, HPS from $H$. polybotrys had remarkable respiration prolonged abilities $(P<0.001)$ as compared to the control group. At the concentration of 0 , 4, and $8 \mathrm{mg} / \mathrm{g}$ for HPS, the respiration lasted $14.3 \pm$ $3.9 \mathrm{~s}, 22.4 \pm 0.9 \mathrm{~s}$, and $22.8 \pm 1.3 \mathrm{~s}$, respectively, representing an increase of $56.7 \%$ for $4 \mathrm{mg} / \mathrm{g}$ and $59.4 \%$ for $8 \mathrm{mg} / \mathrm{g}$. HPS also prolonged the survival time of mice with myocardial ischemia induced by isoprenaline (ISOP) [72]. In addition, $H$. polybotrys also exhibits tonification, growth promotion, analgesic, anti-inflammatory and antiviral activity [65].

\section{Conclusions}

In the literature, chemical investigations and pharmacological activity have been reported for only 21 of the 300 known Hedysarum species. However, members of Hedysarum, such as $H$. polybotrys and $H$. austrosibiricum, clearly possess significant pharmacological potential, especially in the treatment of immune disorders, cancer, diabetes, and hypertension. Investigation into the chemical constituents of plants of genus Hedysarum revealed diverse compounds, including flavonoids, triterpenes, coumarins, lignanoids, nitrogen compounds, sterols, carbohydrates, fatty compounds, benzofuran, and polysaccharides. It should be emphasized that polysaccharides from $H$. polybotrys and $H$. austrosibiricum had particularly prominent immunomodulatory, antioxidant, and anti-diabetic activity, in addition to some other biological properties. Previous studies have provided an empirical base for the medicinal use of Hedysarum species. It is important to note that the safety and toxicity of Hedysarum species have not been explored. There is no published overdose or toxicity data for these species. Therefore, the toxicities of traditional remedies and isolated chemical compounds should be further assessed.

\section{Additional file}

Additional file 1: The chemical structure of compounds isolated from plants of genus Hedysarum.

\section{Competing interests}

The authors declare that they have no competing interests.

\section{Authors' contributions}

DY, ZN, LY, LL, and ZC were involved in preparing the manuscript. LM and TD participated in discussions of views represented in the paper. All authors have read and approved the final manuscript.

\section{Acknowledgment}

This work was financially supported by the Ministry of Science and Technology (2012BA128B02).

\section{Author details}

${ }^{1}$ Department of chemistry, Harbin Institute of Technology, Harbin 150000, China. ${ }^{2}$ Baotou Medical College, No. 31 Construction Road, Baotou, Inner Mongolia 014060, P. R. China. ${ }^{3}$ Beijing Key Lab of Plant Resources Research and Development, Beijing Technology and Business University, Beijing 100048, China.

Received: 27 April 2013 Accepted: 4 July 2013

Published: 18 July 2013

\section{References}

1. Chen DZ: Flora reipublicae popularis sinicae. Beijing: Science Press 1999, 42:180.

2. National Pharmacopoeia Committee: Chinese Pharmacopoeial, China Medical Science and Technology Press; 2010:142

3. Nechepurenko IV, Polovinka MP, Komarova NI, Korchagina DV, Salakhutdinov NF, Nechepurenko SB: Low-molecular-weight phenolic compounds from Hedysarum theinum roots. Chem Nat Compd 2008, 44:31-34.

4. Liu Y, Yang JS: Studies on chemical constituents isolated from Hedysarum polybotrys. Chin Pharm J 2005, 40:1215-1216.

5. Liu Y, Zhang QY, Zhao YY, Wang B, Hai LQ, Ying YP, Chen HB: Saponins from the roots of Hedysarum polybotrys. Biochem Syst Ecol 2007, 35:389-391. 
6. Dang ZL, Liu XH, Zhao AN, Liang JD, Liang J, Liu ZH, Feng SL: Chemical structural features and primary molecular conformation of polysaccharide HPS4-1A from Hedysarum polybotrys. Zhongcaoyao 2013, 44:141-146.

7. Wang W, Liang $H$, Wang B, Tu GZ, Chen HB, Zhao YY: A new natural product from the roots of Hedysarum multijugum. J Peking University (Health Sciences) 2005, 37:532-535.

8. Chen SG: Master's thesis. Studies on the chemical constituents of Hedysarum scoparium and Inula Hupehensis: Lanzhou University; 2007.

9. Neretina OV, Fedorov SV, Gromova AS, Lutskii VI, El'kin YN: Flavonoids of Hedysarum setigerum. Chem Nat Compd 2002, 38:194-195.

10. Neretina OV, Gromova AS, Lutskii VI, Semenov AA, Ushakov IA, Makar'eva TN, Owen NL: Secondary metabolites from Hedysarum setigerum. Chem Nat Compd 2004, 40:91-92.

11. Glyzina GS, Komissarenko NF: The flavonoids of Hedysarum gmelini. Khim Prir Soedin 1967, 3:116.

12. Glyzina GS, Bykov VI: Phenolic compounds of Hedysarum neglectum. Khim Prir Soedin 1969, 5:272.

13. Komissarenko AN, Nadezhina TP, Komissarenko NZ: Flavonoids and xanthones of Hedysarum connatum and $\mathrm{H}$. alpinum. Chem Nat Compd 1994, 30:521-522.

14. Glyzin VI, Bykov VI, Glyzina GS: The phenolic compounds of Hedysarum komarovii. Khim Prir Soedin 1968, 4:324.

15. Glyzin VI, Ban'kovsii Al, Pavlova HS: Phenolic compounds of Hedysarum sachalinense and H. brandtii. Khim Prir Soedin 1970, 6:372.

16. Alaniya MD: Flavonoids of Hedysarum sericeum and H. caucasicum. Plenum publishing corporation 1983, 19:612-613.

17. Hai LQ, XU JJ, Kai Sai-er A, Zhang X, Ma LY: Chemical constituents of Hedysanun austrosibuicum b. Fedtsch. Huaxi Yaoxue Zazhi 2006, 21:47-48.

18. Liu Y, Zhang Z, Zhang QY, Pu XP, Zhao YY: Study on chemical constituents and antioxidative activity of Radix Hedysari. China Pharm 2010, 24:543-549.

19. Liu Y, Zhao YY, Chen HB, Wang B, Zhang QY: Chemical analysis of the principal flavonoids of Radix Hedysari by HPLC. Nat Prod Commun 2010, 5:541-544.

20. Liu Y, Chen HB, Zhao YY, Wang B, Zhang QY, Zhang L, Tu PF: Quantification and stability studies on the flavonoids of Radix Hedysari. J Agr Food Chem 2006, 54:6634-6639.

21. Hai LQ, Zhang QY, Liang H, Zhao YY, Du NS: Study on chemical constituents of Hedysarum polybotrys. Acta Pharm Sinica 2003, 38:592-595.

22. Liu Y, Zhao YY, Tu GZ, Chen HB: Flavonoids of the roots of Hedysarum kirghisorum. Biochem Syst Ecol 2005, 33:809-812.

23. Liu Y, Chen HB, Tu GZ, Zhao YY: Studies on the constituents from the Hedysarum kirghisorum. In Medicinal Plant Research and Traditional Chinese Medicine Modernization-Fourth National Symposium on Medicinal Botany and Herbal Medicine; 2004:167-169.

24. Liu Y, Hai LQ, Zhao YY: Isoflavonoids from Hedysarum semenovii. Chin Pharm J 2009, 44:1533-1535.

25. Xu JJ, Hai LQ, Wang XQ, Chang JM, Zhang X: Chemical constituents of Hedysarum austrosibiricum b. Fedtsch Huaxi Yaoxue Zazhi 2005, 20:214-215.

26. Nechepurenko IV, Polovinka NP, Sal'nikova OI, Pokrovskii LM, Komarova NI, Salakhutdinov NF, Nechepurenko SB: Components of the ethylacetate extract of Hedysarum theinum roots. Chem Nat Compd 2007, 43:5-9.

27. Li YZ, Huang J, Guo HC, Ren B: Chemical constituents from Hedysarum polybotrys and their antitumor activities. Chin Trad Herb Drugs 2009, 40:1195-1198.

28. Wang W, Chen HB, Wang WM, Zhao YY: Studies on flavoniod constituents of Hedysarum multijugum. Acta Pharm Sinica 2002, 37:196-198.

29. Wang $W$, Chen $W$, Chen HB, Liu JQ, Zhao YY: Study on chemical constituents of Hedysarum multijugum. J Peking University (Health Sciences) 2001, 33:205-208.

30. Yang $M$, Wang $W$, Sun JH, Zhao $Y Y$, Liang H, Guo DA: Characterization of phenolic compounds in the crude extract of Hedysarum multijugum by high-performance liquid chromatography with electrospray ionization tandem mass spectrometry. Rapid Commun Mass Spectrom 2007, 21:3833-3841.

31. Chen SG, Chen JJ, Gao K: Prenylisoflavone derivatives from the roots of Hedysarum scoparium. Chem Pharm Bull 2007, 55:1181-1184.

32. Li YS, Chen JJ, Liao XR, Wang HY, Luo SD: Studies on chemical constituents of Hedysarum sikkimense var Rigidum. Chin Trad Herb Drugs 2001, 32:489-490.
33. Nechepurenko IV, Komarova NI, Kuzovkina IN, Vdovitchenko MY Polovinka MP, Salakhutdinov NF: Structure of oligomeric proanthocyanidines from Hedysarum thienum roots studied by thiolysis and MALDI-TOF MS. Chem Nat Compd 2009, 45:420-421.

34. Liu Y, Zhao YY, Chen HB, Zhang QY: Isolation and structural elucidation of an unstable isoflavonoid glycoside malonate from radix hedysari. J Chin Pharm Sci 2010, 19:100-103.

35. Chen SG, Li Y, Zhao J, Gao K: Three new prenylfuranoisoflavonoids from the roots of Hedysarum scoparium. Chin J Chem 2008, 26:531-535.

36. Liu Y, Chen HB, Qiao L, Zhao YY: Two new isoprenyl chalcones from Hedysarum gmelinii. J Asian Nat Prod Res 2005, 7:723-727

37. Rybachenko Al, Kvivut BA, Georgievkii VP: Fluorodensitometric determination of mangiferin and isomangiferin in Hedysarum flavescens and H. Alpinum. Chem Nat Compd 1967, 12:395-396.

38. Denisova OA, Glyzin VI, Rusakova SV, Pimenov MG: Xanthone C-glycosides of Hedysarum denticulatum. Chem Nat Compd 1977, 13:245.

39. Glyzin VI, Ban'kovsii Al, Pimenov MG, Boryaev Kl: Xanthone glycosides of Hedysarum flavescens. Chem Nat Compd 1973, 9:409-410.

40. Liu Y, Hai LQ, Zhao YY, Zhang QY: Studies on the chemical constituents of Hedysarum semenovii. China Pharm 2008, 22:568-569.

41. Wang W, An DG, Chen HB, Tu GZ, Zhao YY: Two new pterocarpenes from Hedysarum multijugum. J Asian Nat Prod Res 2003, 5:31-34.

42. Miyase T, Fukushima S, Akiyama Y: Studies on the constituents of Hedysarum polybotrys Hand-Mazz. Chem Pharm Bull 1984, 32:3267-3270.

43. Tian HY, Liu QG: A study on the chemical constituents of Hedysarum Taipeicum (Hand-Mazz) K T Fu. J Southwest Nationalities Collge Nat SC 1996, 22:182-184.

44. Liu Y, Ma XX, Chen HB, Tu GZ, He JM, Zhao YY: Chemical constituents of Hedysarum gmelinii. J Chin Pharm Sci 2005, 14:75-78.

45. Hai LQ, Zhang QY, Wang Y, Zhao YY: Study on chemical constituents of Hedysarum polybotrys (IV). Lishizhen Med Materia Medica Res 2006, 17:1659.

46. Liu Y, Zhang QY, Chen HB, Wang B, An DG, Zhao YY: Structural determination of saponins from Hedysarum polybotrys. Magn Reson Chem 2006, 44:1128-1130.

47. Wang W, Hai LQ, Zhao YY, Chen HB, Wang B, Liang H: Saponins from roots of Hedysarum multijugum. China J Chin Mat Med 2007, 32:315-317.

48. Liu Y, Zhao YY, Chen HB, Wang B, Zhang QY: Structure elucidation and complete NMR spectral assignment of two triterpenoid saponins from Radix Hedysari. Fitoterapia 2009, 80:127-129.

49. Wang W, Zhao YY, Liang H, Jia Q, Chen HB: Coumestans from Hedysarum multijugum. J Nat Prod 2006, 69:876-880.

50. Neretina OV, Gromova AS, Lutskii VI, Semenov AA, Ushakov IA Dmitrenok PS, Oven NL: Isolariciresinol glucoside, berberine, and phenolic acid from the aerial part of Hedysarum setigerum. Chem Nat Compd 2004, 40:609-610

51. Hui HP, Feng SL, Zhao LG, Shi YK, Liu XH: Purification and structure identification of HPS. LiShizhen Med Materia Medica Res 2010, 21:2302-2303.

52. Wang W, Zhao YY, Wang B, Liang H, Tu GZ, Chen HB: Two new arylbenzofurans from the roots of Hedysarum multijugum. J Asian Nat Prod Res 2007, 9:19-22.

53. Zou K, Katsuko K, Zhu S: A novel compound from Hedysarum polybotrys. J Asian Nat Prod Res 2007, 9:699-703.

54. Cheng F, Zou K, Zhu S, Katsuko K: A new phenylpropionate derivative from the rhizomes of Hedysarum polybotrys. Chi J Nat Med 2009, 7:351-353

55. Kukushkina TA, Vysochina GI, Karnaukhova NA, Selyutina IY: Content of mangiferin and total amount of xanthones in plants of some wild-growing and introduced Hedysarum (Fabaceae) species. Rastitel'nye Resursy 2011, 47:99-106

56. Ma D, Feng SL, Zhao LG, Liu XH, Li B, Li XD, Hu FD: Purification of the radix Hedysari polysaccharide and determination of its constitution. Chin JAMP 2008, 25:177-179.

57. Hikino H, Funayama S, Endo K: Hypotensive principle of astragalus and Hedysarum roots. Planta Med 1976, 30:297-302.

58. Shi YK, Zhao LG, Liu XH, Hu FD, Cui F, Bi YY, Ma YF, Feng SL: Structural characterization of a sulfated glucan isolated from the aqueous extract of Hedysarum polybotrys Hand.-Mazz. Carbohydr Polym 2012, 87:160-169.

59. Tibe O, Meagher LP, Fraser K, Harding DRK: Condensed Tannins and Flavonoids from the Forage Legume Sulla (Hedysarum coronarium). J Agr Food Chem 2011, 59:9402-9409. 
60. Hui HP, Feng SL, Hu FD, Cui F, Wu YQ: Study on antioxidative activity of polysaccharide from Radix Hedysari in vitro. J Anhui Agri Sci 2010, 38:4056-4057.

61. Qiu T, Bai J, Jiang Y, Huang ZL: The effect of HPS on RNA and DNA content in several organs of mice. Chin Trad Pat Med 1992, 14:33-34.

62. Zhang JP, Guo LP, Ruan SY: The effect of HPS on LPO and SOD content in SMC of rabbits. J Gansu College of Trad Chin Med 1992, 9:3.

63. Hai LQ, Kang JS, Sun L: Effects of aqueous extract of Hedysarum austrosibiricum on metabolism of oxyen free radicals in subacute aging mice caused by D-galactose. China J Chin Materia Medica 2007, 32:729-731.

64. Mao XJ, Wang JZ, Wang FL: Effects of radix hedysari polysaccharide (RHPS) \& astragali polysaccharide (APS) on immune functions. Chin Pharm Bull 1989, 5:367-372.

65. Quan JX: The pharmacological research on Hedysari. LiShizhen Med Materia Medica Res 1997, 8:178-180.

66. Wang W, You CG, Wang Y, Wang CM, Hu JC, Zheng HJ: The RHTS enhancement to the function of mouse immunocytes and its relation with CaM levels in the cells. J Lanzhou University 2000, 5:112-116.

67. Yu L, Cao Y, Wei X, Xu L, Fang TH: The Immuno regulation effects of different extracts from radix Astragali and radix Hedysari. J Anhui Agri Sci 2010, 38:20623-20624.

68. Wei DF, Zhang LF, Cheng WD, Gui MM, Li XY, Wei YX, Bao YC: Comparative study of Hedysari Radix and Astragali Radix alternative classic tonification prescriptions on humoral immunity in immunosuppressed mice. Zhongyaocai 2012, 35:944-948.

69. Li SG, Wang DG, Tian W, Wang XX, Zhao JX, Liu Z, Chen R: Characterization and anti-tumor activity of a polysaccharide from Hedysarum polybotrys Hand.-Mazz. Carbohydr Polym 2008, 73:344-350.

70. Hu FD, Li XD, Zhao LG, Feng SL, Wang CM: Antidiabetic properties of purified polysaccharide from Hedysarum polybotrys. Can J Physiol Pharm 2010, 88:64-72.

71. Wei SY, Zhang PX, Han N, Dang Y, Zhang HB, Zhang DY, Fu ZG, Jiang BG: Effects of Hedysari polysaccharides on regeneration and function recovery following peripheral nerve injury in rats. The American J Chin Med 2009, 37:57-67.

72. Huang ZL, Cui ZM, Ren Y, Zhang J: Pharmacological effects on HPS complexes. J Gansu College of Trad Chin Med 1987, 3:40-43. 